\title{
Svar til svaret
}

"Hamsun i nord og Hamsun i sør. Kunsten å argumentere for et diktersenter" har provosert førstekonservator Alvhild Dvergsdal i den grad at hun over åtte sider ispedd utropstegn forklarer hva som er galt med artikkelen. Det meste viser det seg. Jeg bygger på altfor lite og feil materiale og burde ha gått mye lenger tilbake i historien for å kunne diskutere hvorfor planene om et diktersenter viet til Knut Hamsun ble realisert på Hamarøy, men ikke i Grimstad. Blant mye annet er jeg "uredelig", "meget retorisk" og "urettmessig respektløs", jeg "mistenkeliggjør", foretar "argumentatoriske saltomortaler" og lar meg "ikke stoppe" av noe. Fagfellene som har vært inne i bildet? - De er "svake" og står følgelig i stil med min manglende kompetanse.

Leserne får vurdere selv. Men at jeg skal ha brunskvettet befolkningen i Nordland og bagatellisert krigsårenes lidelser for landsdelen, faller på sin egen urimelighet. Det jeg gjorde i artikkelen, var å undres hvorfor det har vært umulig å få oppkalt en eneste gate etter Hamsun sørpå, mens man nordpå ikke bare fikk etablert et eget diktersenter i et ikonisk nybygg, men at den lokale videregående skolen er oppkalt etter dikteren. Da var det ikke urimelig å tenke seg at Hamsuns nazisympatier og støtte til okkupasjonsmakten under krigen hindret oppkallinger og nybygg til hans ære sørpå, mens det tydeligvis ikke var tilfellet nordpå.
Jeg tar til etterretning at Dvergsdal i tillegg til å påskrive mitt forskerpass så ettertrykkelig, synes å ville definere premissene for hvordan man etter hennes mening burde skrive om senteret. Den som ytrer seg kritisk, skal ikke dø i synden. Seg selv gir hun skussmål for å være «god og grundig» $i$ et arbeid jeg hadde kommentert på en måte hun mislikte.

Som ansatt på Hamsunsenteret taler ikke Dvergsdal fra et nøytralt, interesseløst sted. Slik det presiseres i de to dokumentene jeg tok utgangspunkt i (Virksomhetsplan, 2005; Grunnbok, 2008), skal senteret både formidle et omdiskutert forfatterskap og selge et "reiselivsprodukt" - "merkevaren Hamsun" - til "betalingsvillige målgrupper". Det har vært folk som har skrevet på tvers av senterets interesser før meg, og det vil helt sikkert komme flere etter.

Marianne Egeland, professor, Institutt for lingvistiske og nordiske studier Universitetet i Oslo r.m.egeland@iln.uio.no

Postboks 1102 Blindern, 0317 Oslo, Norge 